Special Section : Rocky Plateaus

\title{
Research Paper \\ Ecohydrologic Description of Springs in the North Western Ghats, Maharashtra
}

\author{
Jared Buono, Renie Thomas, Himanshu Kulkarni, Kaustubh Mahamuni, Manasi Karandikar, Ketaki \\ Ghate, Ketaki Kulkarni, Neethi Mahesh, Dhananjay Ambrale, Ashok More
}

Dr. Jared Buono is a consulting ecohydrologist based in Bengaluru. He has worked on community-based water security across India and in twelve other countries. He currently leads the Springs Initiative, an association of NGOs and government departments working toward better awareness and policy on springs.

Email : jared.buono@gmail.com

Renie Thomas is a geologist whose research focusses on Deccan basaltic lava flow architecture, groundwater and ecosystem health. He possesses a masters degree in Geology and a diploma in Natural Resource Management and nature conservation.

Dr. Himanshu Kulkarni leads ACWADAM, a leading knowledge partner and think tank on India's groundwater management paradigm. He is a hydrogeologist by qualification and has been working on aquifers and groundwater across India's diverse groundwater typology for more than thirty years.

Kaustubh Mahamuni is a hydrogeologist with ACWADAM who has mapped springs and lead capacitybuilding programmes throughout India and the Himalayan region.

Ketaki Ghate and Manasi Karandikar are Co-founders and Managing Partners at oikos for ecological services. They are also Faculty, Trustee and core team member at Ecological society. They have worked on various biodiversity assessment, land mapping, planning and development aspects and initiated nature conservation perspective in land development.

Ketaki Kulkarni is Project Assistant at oikos for ecological services and worked on various projects for ecoeducation, eco-assessment, habitat analysis and mapping. She has been a Spark fellow at BAIF and worked on restoration of Sacred groves with community participation.

Neethi Mahesh is a Freshwater Ecologist with the Mahseer Trust, based in Bengaluru. Her research focus is on freshwater habitat conservation.

Dhananjay Ambrale is a Field Administrator at Grampari, an NGO operating in Satara District, Maharashtra. His focus is on supporting watershed and spring protection programmes.

Ashok More is a farmer and Field Assistant at Grampari, an NGO operating in Satara District Maharashtra. His focus is mainly on mapping hydrogeology and community mobilization around spring protection in the North Western Ghats.

\begin{abstract}
Springs are essential components of the freshwater resources in the North Western Ghats yet they are not well studied and are under threat from ecological degradation. This study surveyed ecology and hydrogeology of five springs. Observations included geology, flora, fauna and impact of human pressures. The goal was to describe the range of ecological conditions to improve baseline understanding. Results show that spring recharge and discharge areas were found to hydrologically connect separate parts of the landscape, sometimes spanning different watersheds. While spring discharge is likely controlled in large part by catchment size and aquifer characteristics, impacts from human pressures may reduce spring discharge or water quality. Reduction in spring discharge may reduce biodiversity, particularly at the spring outlet where natural ponds or wetlands may dry up and destroy freshwater habitat. Grazing, fire, construction, pumping and fuel wood collection were common human pressures effecting nearly all springs. Discussed are refined definitions of a spring shed and recommendations for future assessment, conservation and management efforts.
\end{abstract}

Keywords : aquifer, biodiversity, ecosystem, hydrogeology, spring shed, groundwater 


\section{Introduction}

The Western Ghats mountain range represents one of the world's biodiversity hotspots and spanning much of India's west coast, supports over 400 million people with water, food and other ecosystem goods and services (Walker and Meyers 2004). The provision of these services, however, is threatened by widespread environmental degradation. It is estimated that as little as $6 \%$ of the historic vegetation cover now remains intact due to high population density and intensive land use (Aravind et. al. 2011), with many remaining endemic species threatened (Watve 2006; Watve 2013). This loss of biodiversity is likely to have significant economic, social and environmental consequences for millions of people, but the precise impacts are not yet known and require additional study.
The freshwater systems are of particular interest as India faces a deepening water crisis. The Western Ghats constitute the headwaters for almost all rivers basins in central and south India. The rivers, lakes, wetlands, springs and aquifers are used for drinking water, household use, irrigation, power generation, industry, and tourism across eight states. They also provide unique habitats on which millions of people depend for livelihoods and food sources. (Aravind et. al. 2011). These water bodies, although a small fraction of the total land area, can support entire ecosystems, and areas such as wetlands are responsible for up to one fifth of local biodiversity (Space Applications Centre 2011).

Freshwater systems are also some of the most sensitive and threatened ecosystems (Bassi et. al. 2014), the main threats in the Western Ghats being

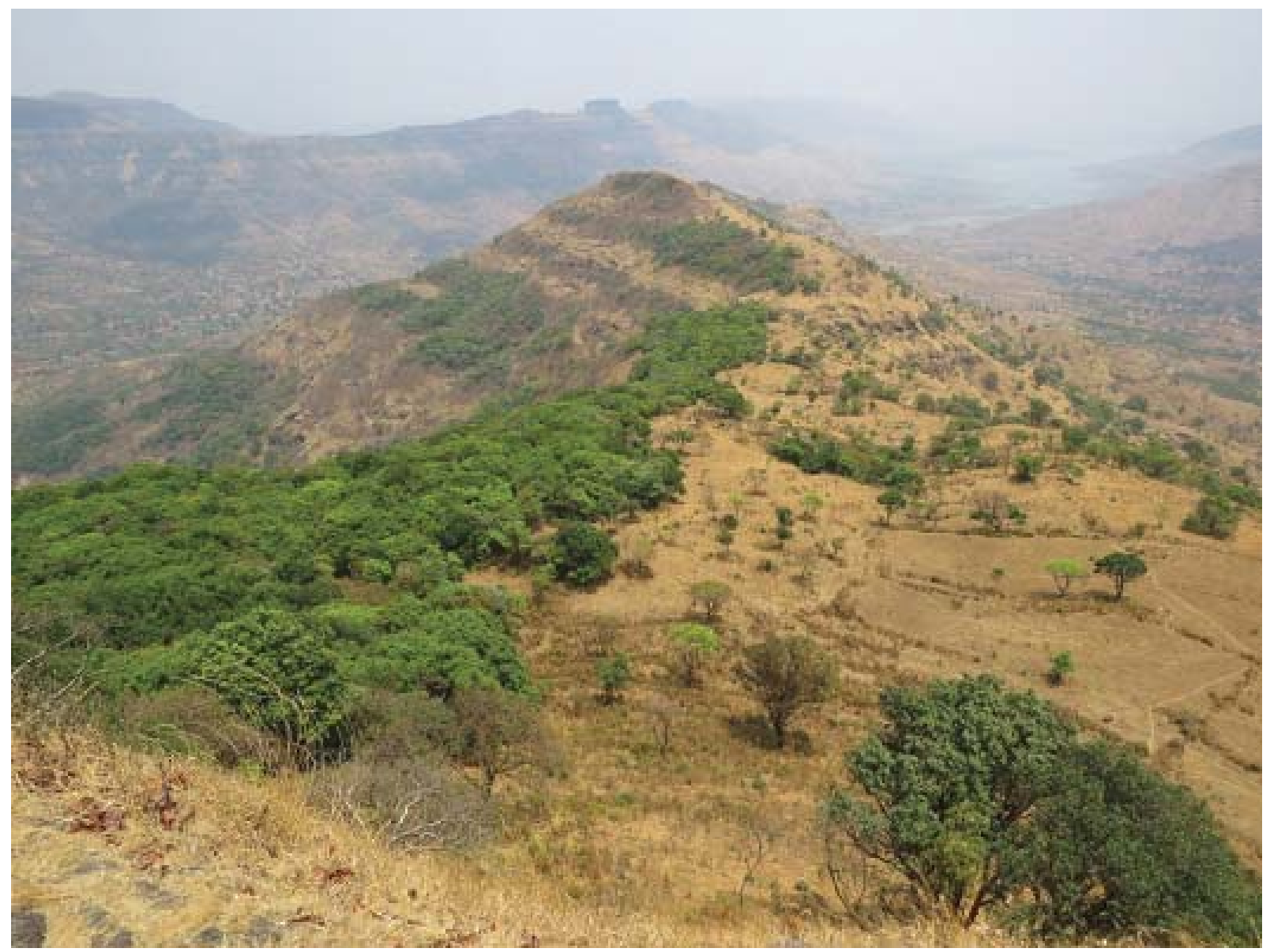

Figure 1: The typical landscape of the North Western Ghats showing the plateau and valley formations and characteristic horizontal banding due to geology and its influence on vegetation (gallery forests). Anthropogenic impacts can also be seen including a loss of tree cover on the southern aspects (right-hand foreground) due to pressures of annual burning, intensive grazing, wood collection and farming. 
construction, agriculture, pollution, groundwater exploitation, invasive species and deforestation (see Figure 1). Many freshwater plants and animals are routinely harvested for food and livelihood activities. These systems face such intensive anthropogenic pressure, that at least $18 \%$ of freshwater taxa are threatened with extinction (Aravind et. al. 2011).

One of the lesser studied components of the Western Ghats is the natural springs which occur when groundwater intersects the landscape and flows onto to the surface. Although the number and extent of springs is not known, they appear ubiquitous across the mountain range and may be integral to the entire freshwater resource. For example, many if not most of the rivers, lakes and wetlands in the mountain range are spring derived. For the people of the mountains, springs have been used for generations as a source of safe, perennial drinking water, small-scale irrigation and distributed water points for domestic animals (Naik et. al. 2002). Springs also provide cultural and religious value as many temples are built on and around springs, such as the Old Mahabaleshwar Temple at the source of the Krishna River in Maharashtra.

But there are signs that springs are under threat and there is increasing concern about declining spring discharge and water quality. Temple springs are going dry, spring-fed village water tanks no longer provide adequate household supply, and community drinking water springs are being abandoned due to contamination. Most of these occurrences appear to be related to increasing human impacts such as groundwater exploitation, deforestation of recharge areas, and improper sanitation. However, few of these anecdotal examples have been documented and there is little baseline information on springs in general.

The present study was conducted to expand our understanding of the role and current status of springs in the North-Western Ghats. In particular, the objective was to advance a general description of springs in the Western Ghats to develop a baseline for future monitoring and management.

\section{The Geology of Western Ghats}

This study focused on the North-Western Ghats which is hydrologically distinct from the southern part of the range. The section extending from the Karnataka border towards north up to Gujarat is dominated by the Deccan Volcanic Province, volcanic rocks formed by outpouring of basaltic lava flows (approx. $65 \mathrm{my}$ ) with near horizontal layers called flood basalts, which occur in simple and compound pahoehoe type flows
(Deolankar 1980, Deshmukh 1988) (Figure 2.a). This is what creates the characteristic landscape of flat-topped plateaus and horizontal banding of the mountains (Figure 1).

The typical geologic cross section in this area consists of alternating units of relatively dense, compact basalt interspersed with layers of relatively porous, or vesicular sections - the result of lava morphology that also affects the nature of weathering, joints and fractures between the two formations (Kulkarni and Deolankar 1995; Kale and Kulkarni 1992). Hydraulic conductivity in the vesicular basalts is greater than that in the compact basalts because, in addition to vesicular pore space, the former tends to be more heterogeneous and more prone to weathering while the compact basalt tends to be more homogenous, have less jointing and be more resistant to weathering (Deolankar and Kulkarni 1987). Therefore, the vesicular basalt tends to store and transmit groundwater while the compact basalt tends to limit groundwater. Springs are formed when groundwater in the vesicular basalt percolates down to a compact basalt layer and moves laterally to emerge on the surface (Naik et. al. 2002). Springs such as this, formed when groundwater flow is impeded by an impervious material, are called fracture springs (Bryan 1919).

Important water bearing rock formation in the area is laterite. This is highly weathered basalt that caps many of the plateaus (see Figure 2.b) and has a high porosity and specific yield relative to other basalt formations (Widdowson 1997; Widdowson and Cox 1996, Widdowson and Gunnell 1999). Many springs are associated with the contact between laterite and compact basalt or other impervious layers (Naik et. al. 2002).

Finally, there are a series of fracture zones, or lineaments that cross the landscape. The superimposition of post volcanic tectonics, these N-S trending fractures increase hydraulic conductivity and often connect vertically separated water bearing formations contributing to movement of groundwater at the landscape scale (Kulkarni and Deolankar 1997; Duraiswami et. al. 2012, Duraiswami 2013). Some springs emerge directly from these fractures; these are defined as fracture springs (Bryan 1919).

\section{Study Area}

The location of the study area is in the subcatchment of river Krishna. The springs surveyed were centered on the town of Panchgani, a hill station in Satara District, Maharashtra (Figure 2.b). Rainfall in this area is highly variable but averages $2000 \mathrm{~mm}$ 


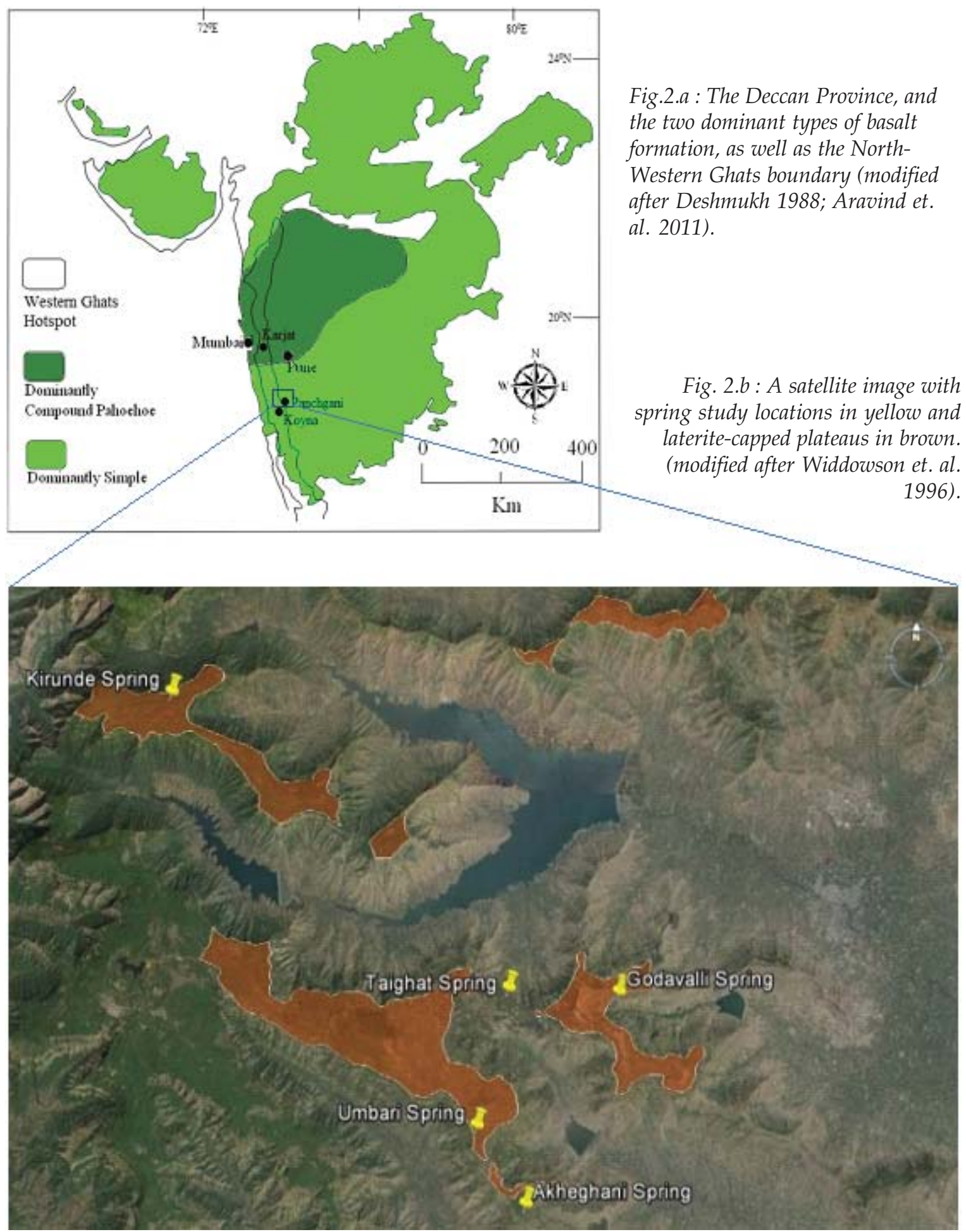


annually at Panchgani. The terrain is characterized by broad flat plateau top mountains and deep valleys with a range of dense forest types and grasslands. Settlements include semi-urban hill stations and rural farm communities.

\section{Methods}

\section{Approach}

The focus was on observations of hydrogeology, and ecology including plants, animals and human pressures and impacts. A small number of springs were examined in detail, with locations chosen to represent the range of conditions - from springs in remote locations that were relatively untouched, to heavily impacted, urbanized springs. The goal was to describe the historic, native ecological conditions of a typical spring, as well as the range of conditions that occur under various levels of human impact. Five springs were selected from project sites of a local NGO, Grampari, who has been for several years' actively managing springs with local communities for their drinking water needs. The rapport with the community was useful for determining spring water use and history. Other criteria for choosing these springs included accessibility, observed human impact and land use. See Figure 2.b for spring locations.

\section{Hydrogeology Methods}

Geology was mapped in the area of each spring taking transects from ridge to valley. Locations of geologic features and structures were recorded on GPS including rock type, contacts between rock formations, joints and fractures. Satellite imagery from Google Earth was also used to identify larger structures such as landscape-scale fracture systems. For each study site a geologic cross section was developed. The crosssection enabled a determination of the type of spring and provided an estimate of the extent of the potential aquifer and the likely recharge areas. These areas were visited and, based on topography or other relevant geologic features; the catchment area of the spring was delineated. These were used to inform the ecological observations of the larger 'spring shed', not just the spring outlet.

Spring discharge was measured at the spring outlet by timed volumetric samples. Discharge was measured in the hot season (between March and May) to determine the lower bounds of water flow and to identify whether the spring was perennial or seasonal.

\section{Ecology Methods}

Field surveys were conducted quarterly at each study site over a one-year period between March 2014 and March 2015. Observation teams included fauna and flora experts as well as a geologist and local community members. Transect walks were conducted within the spring shed - including the spring outlet and catchment area. Surveys included inventory of flora and fauna species, identification of human pressures, impact, and land classification.

Flora and Fauna Inventory: Observations of trees, shrubs, birds, reptiles, mammals and amphibians were conducted by the team of experts at each site. All individual species were recorded whenever possible; otherwise a large representative list was created. Special attention was given to invasive and non-native vegetation species and faunal observations at the spring outlet where biodiversity appeared high.

Human Use, Impact and Land Classification: Human pressures were recorded under direct observation and with interviews with community members. Drivers of human pressures include type and intensity of grazing, annual burning, extent and intensity of harvesting of wood, wild food or other forest/land product, extent of agriculture, construction, and groundwater pumping. Particular attention was given to the spring outlet which tended to have intensive use by domestic animals or the community in terms of infrastructure to harvest spring water. Human impacts as a result of these pressures was similarly observed: the number of domestic animals or signs of grazing, density of footpaths, extent of cut trees, signs of accelerated erosion, etc.

Land use was also classified for each spring catchment using satellite imagery and field verification. Cover classes were developed after initial observations with the following definitions :

Dense Canopy - where tree spacing is less than $3 \mathrm{~m}$ to $4 \mathrm{~m}$, with closed canopy and touching crowns, and multistory vegetation showing a mixed age class of trees, shrubs, herbs and climbers. This class represents the minimum human interference.

Plateau - areas with relatively flat surfaces surrounded by steep slopes. These are the characteristic plateaus of the area.

Rocky Area - areas with exposed outcrops and little soil or vegetation due to either erosion or natural means.

Shrubbery - areas dominated by shrubs or small trees up to $3 \mathrm{~m}$ height. This class could vary depending on whether the shrubs were sparse or dense. 
Fields - dominated by areas under cropping or other intensive agricultural practices.

Settlement - areas showing significant human activity such as any kind of infrastructure, construction, roads, houses, etc.

Grassy Patches - open areas dominated by herbaceous vegetation.

Regenerating Forest - areas showing secondary growth, with smaller trees, dense undergrowth, and higher proportion of invasive species in some cases.

\section{Results}

Spring discharge ranged from 31 to 0 litres per minute in the hot season when flow is lowest. Elevations of spring outlets ranged from 1170 to 1240 meters and the size of spring catchments ranged from 6.1 to 15.8 hectares. All but one spring was determined to be a contact-type spring - meaning the spring is created when groundwater contacts a relatively impervious layer and emerges on the surface. The aquifers were generally associated with laterite rock and soils while the impervious zones were either compact basalt or lithomarge.

Catchments ranged from dense, mature forests to urbanized areas, while spring outlets ranged from completely covered by springbox infrastructure to natural, open pools with diverse animal and plant life. Human pressures included annual burning, grazing, tree cutting and fuel collection, construction, and groundwater pumping. Trampling and soil compaction were also observed at many spring outlets.
Specific results for each spring study location are given below, with summary information and coordinates of spring catchment centroids given in Table 1.

\section{Akhegani Spring}

This spring is located within the village of Akhegani in Jaoli Block, Satara District. The spring outlet and catchment area are several kilometers away from habitations, with the water being gravity-fed to the community via pipes (see Figure 3). The geological survey suggested that groundwater is being recharged through fractures on the plateau above, and through the deep lateritic soil and talus of the adjacent slopes. Percolation occurs through the soil-talus complex until an impervious lithomarge is reached. The spring outlet emerges along roughly 10 meters of the horizontal contact of the lithomarge making this a contact spring. However, other springs in the area occur not along the contour of the lithomarge but along the slope-line of nallas indicating fracture springs. Spring discharge was measured as 15 liters per minute on April 14, 2014.

Land cover classes were observed as :

$\begin{array}{lll}\text { Land Cover Class } & \text { Area (hectares) } & \text { Area (\%) } \\ \text { Regenerating Forest } & 5.7 & 92 \\ \text { Settlement } & 0.4 & 6 \\ \text { Grassy Patch } & 0.1 & 2 \\ \text { Total } & \mathbf{6 . 2} & \mathbf{1 0 0}\end{array}$

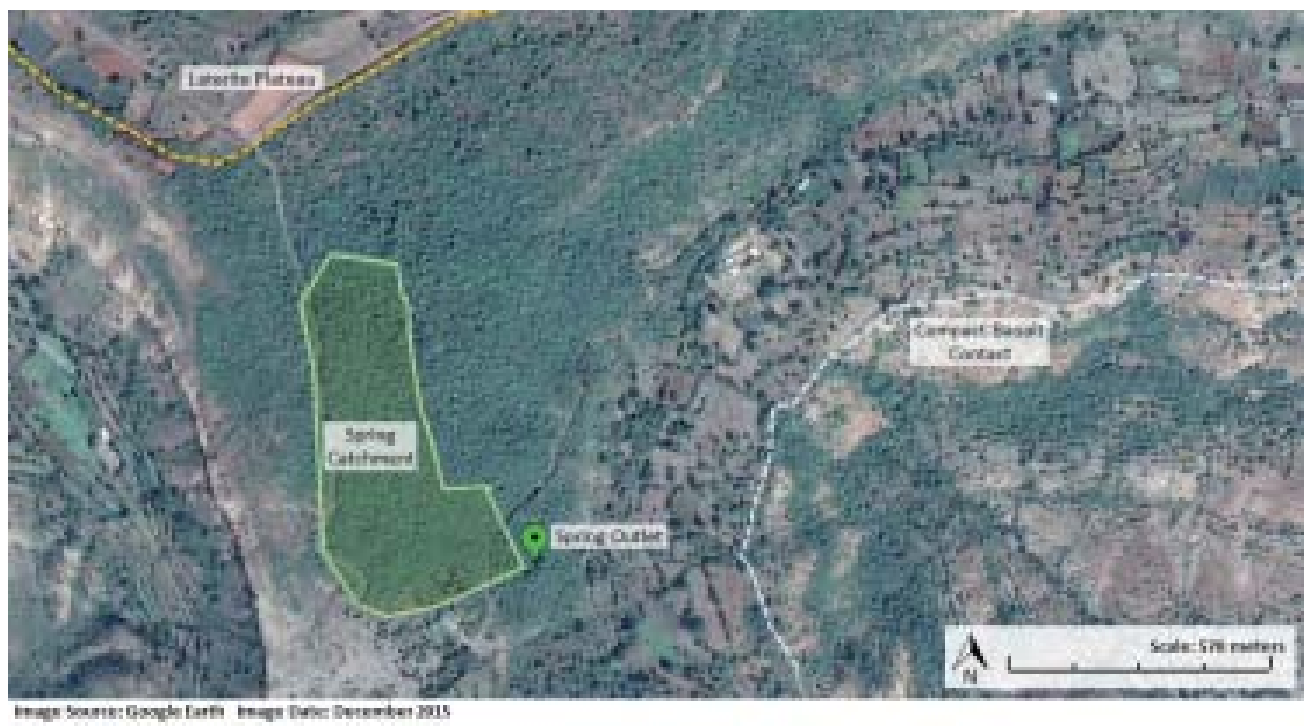

Figure 3: Akhegani Spring and surrounding area. The village sits to the west of the image. 
The area of both the spring outlet and catchment were similar - forested with a closed deciduous canopy of moderate density and a stratified structure showing some shrubs, climbers and the presence of regenerating species. The dominant tree species included Tambat (Flacourtia indica), Jambhul (Syzygium cuminii), and Pisa (Actinodaphne hookeri). The dominant shrubs found were Phapat (Pavetta crassicaulis), Toran (Ziziphus rugosa), Alu (Meyna laxiflora) and climbers like Ambulki (Elaegnus latifolia). In terms of fauna, birds like Red vented Bulbul, Red whiskered Bulbul, Common Iora, Grey Jungle Fowl, Coppersmith Barbet, White cheeked Barbet were heard and seen. Amphibians like Indirana spp. were observed inside the spring box. It should be noted that all springs in the area were modified with a springbox. These are generally plastered brick boxes built at the spring outlet to collect water for community use - see Figure 6 for an example.

Human pressures in the area include moderate encroachment on the forest in the springshed, particularly from clearing for construction and wells. Grazing, fire and tree cutting are present but limited as much of the springshed is on Forest Department land. In the more pressured areas, where the canopy has been opened from tree loss, the Forest Department has undertaken restoration and recharge practices such as infiltration basins, tree plantings and farm ponds.

\section{Godavalli Spring}

The Godavalli village is located on the south slope

of Panchgani Tableland. Panchgani town, a popular tourist destination, borders the village. Therefore, recent growth has been rapid and the village's character is changing from a rural farming community to a more urban centre with hotels, schools and weekend homes.

The geological survey indicated that recharge of groundwater occurs on the laterite plateau and the adjoining slopes which are comprised of vesicular basalt. The spring emerges at the lowest point in the village, along the contact with compact basalt. A fracture zone runs approximately NW-SE through the village that appears to help carry water from the plateau to the spring (see Figure 4). According to community members, the temple in the village was built around the spring generations ago. However, over the last few years, the spring is no longer perennial and goes dry by March. The spring was not flowing during our spring survey; thus no discharge was recorded.

Land cover classes were :

$\begin{array}{lll}\text { Land Cover Class } & \text { Area (hectares) } & \text { Area (\%) } \\ \text { Dense Canopy } & 1.4 & 9 \\ \text { Plateau } & 0.8 & 5 \\ \text { Fields } & 2.1 & 14 \\ \text { Settlement } & 4.6 & 30 \\ \text { Grassy Patches } & 6.5 & 42 \\ \text { Total } & \mathbf{1 5 . 4} & \mathbf{1 0 0}\end{array}$

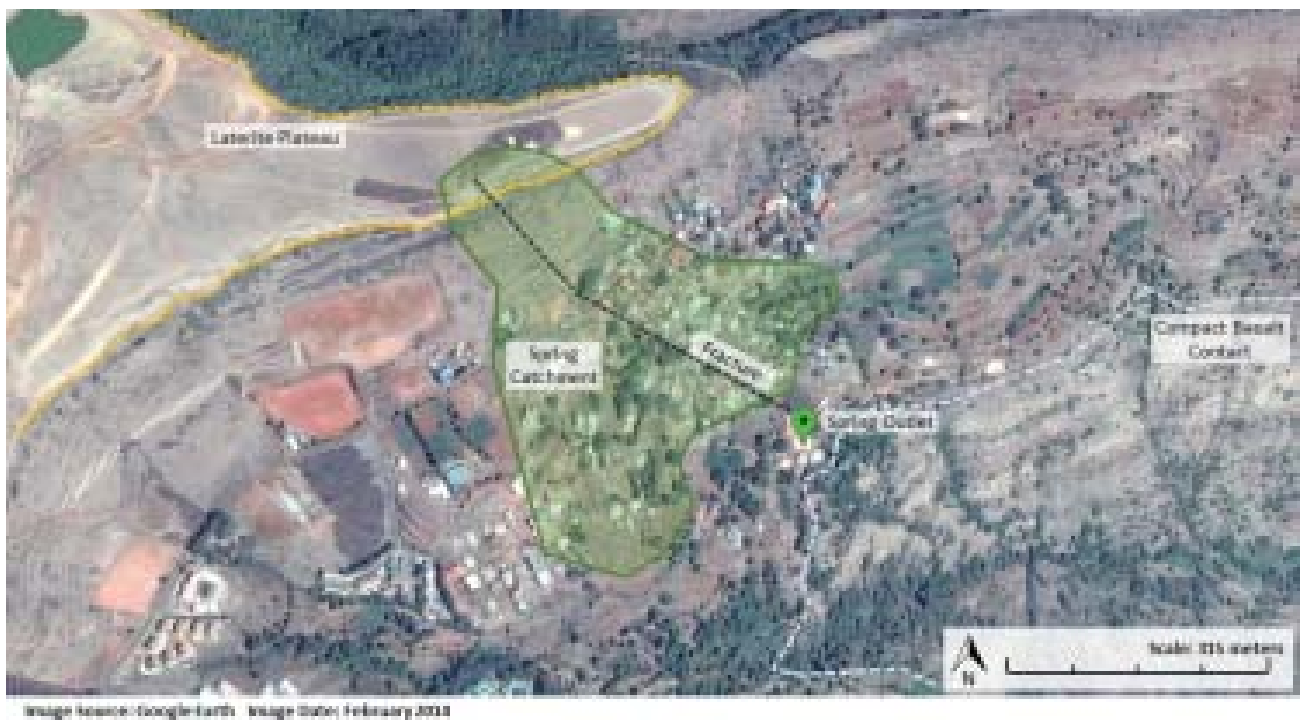

Figure 4: Godavalli Villages showing the location of the spring outlet, catchment and geologic features. 
The village shows presence of large, old trees. The dominant species found were Mango (Mangifera indica) and Jackfruit (Artrocarpus heterophyllus). However, little of the historic vegetation remains as most of the trees were planted domestically. Several invasive and nonnative species were observed. Birds observed were Common Kestrel, Golden Oriole, Red vented Bulbul, Common Myna, Jungle Crow, House Sparrow, Red whiskered Bulbul, Coppersmith Barbet. Overall, however, biodiversity was low due to the proximity of urbanized area. There is intensive and continual pressure from grazing, agriculture, fuel wood collection, construction, groundwater pumping, tourism and annual burning.

\section{Kirunde Spring}

Located near the village of Kirunde, the spring is in a sparsely populated area. The catchment is on a high elevation lateritic plateau with deep soils and dense forest. The geological survey indicated that groundwater recharge occurs in the deep soils on top of the plateau and passes through laterite and vesicular basalt via a fracture system. The spring emerges just above the contact with the compact basalt. Discharge is very high (31 liters per minute in the dry season) and the flow is perennial. The catchment area on the plateau is dominated by dense forest canopy with stratified layers. Species included mature Jambhul (Syzygium cuminii) trees and a few specialized trees like Narkya (Nothapodytes nimmoniana) and Garcinia spp were also observed. The shrubs principally included Alu (Meyna laxiflora) and Karwand (Carissa congesta). Numerous animals were observed such as langur, wild pig, barking deer, and reptiles such as Brook's gecko, Pit Vipers, Rat snake, and Keelback. Leopard tracks were observed during one survey and sightings by community members confirmed their presence.

Land cover classes were observed as :

$\begin{array}{lll}\text { Land Cover Class } & \text { Area (hectares) } & \text { Area (\%) } \\ \text { Dense Canopy } & 11.2 & 71 \\ \text { Regenerating Forest } & 1.4 & 9 \\ \text { Settlement } & 0.05 & 0.1 \\ \text { Rocky } & 0.3 & 2 \\ \text { Fields } & 1.1 & 7 \\ \text { Grassy Patch } & 1.7 & 11 \\ \text { Total } & \mathbf{1 5 . 7} & \mathbf{1 0 0}\end{array}$

Human pressures are limited. There is only one family regularly utilizing the catchment for grazing, fuel wood and agriculture - the house and agricultural fields are clearly visible at the north end of the catchment in Figure 5. The spring outlet is also in a

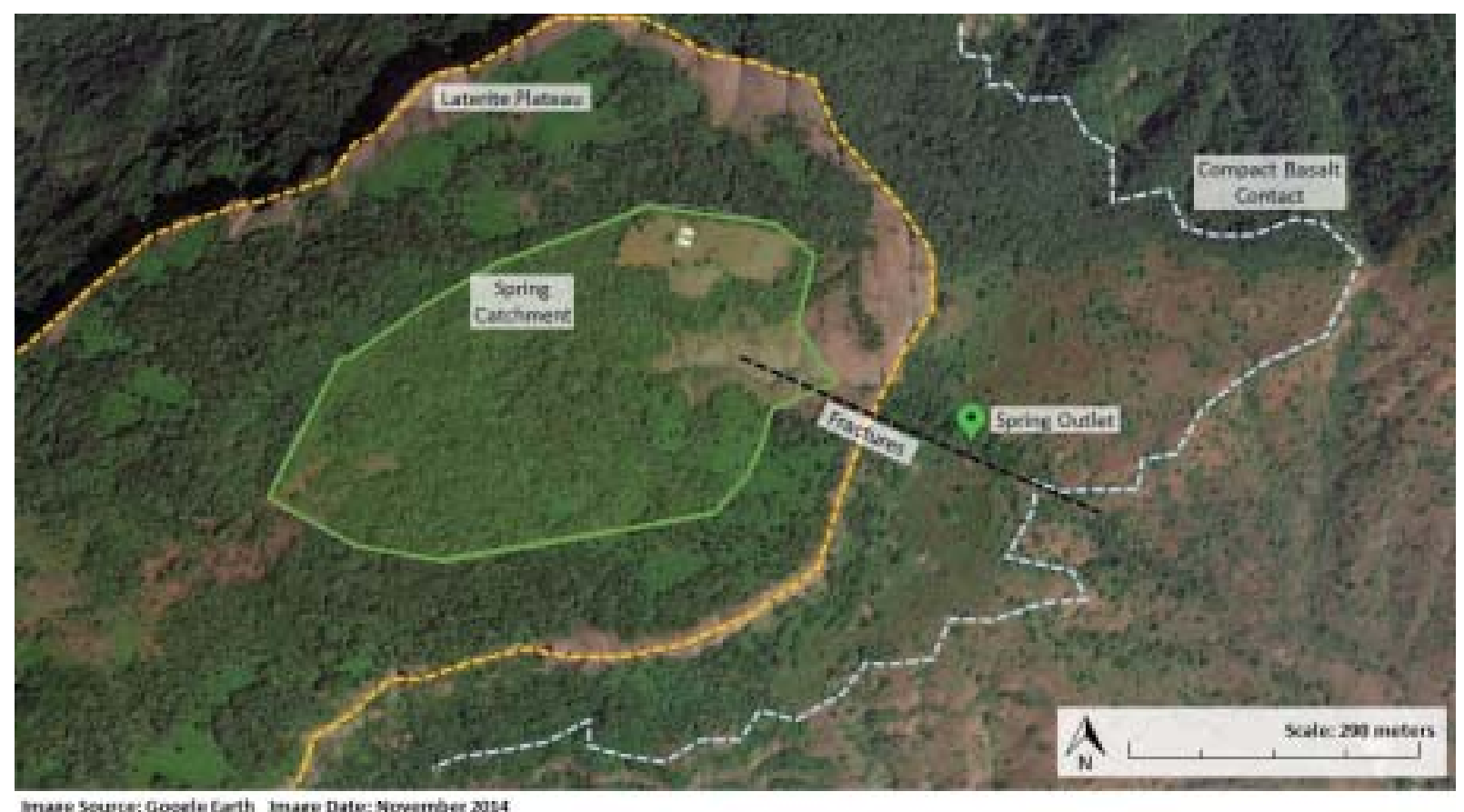

Figure 5: Spring at Kirunde and geologic features. The one habitation can be seen on the north side of the catchment. 
relatively native state. It sits over a kilometer from the village and has not been altered with a springbox or

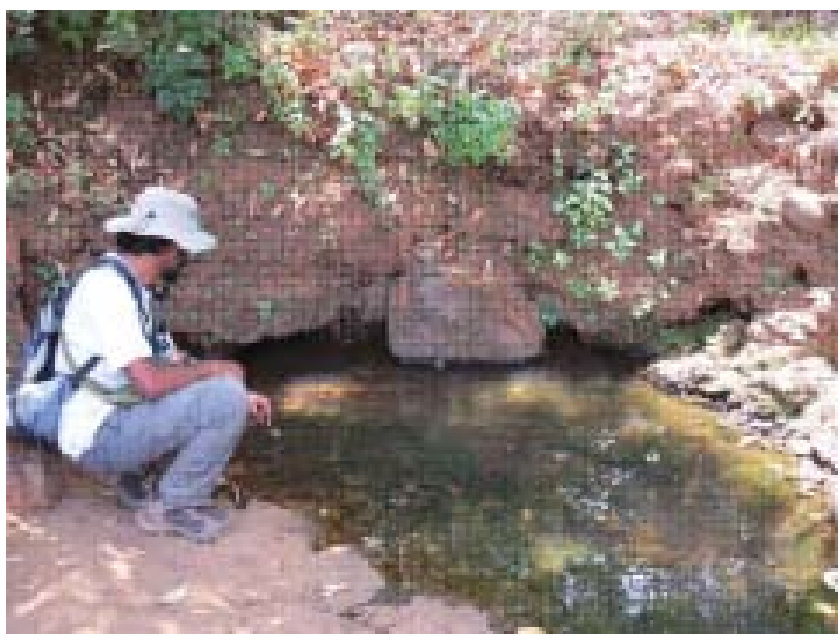

(a)
House Sparrow. A few raptors like Common Kestrel and Black Kite were observed.

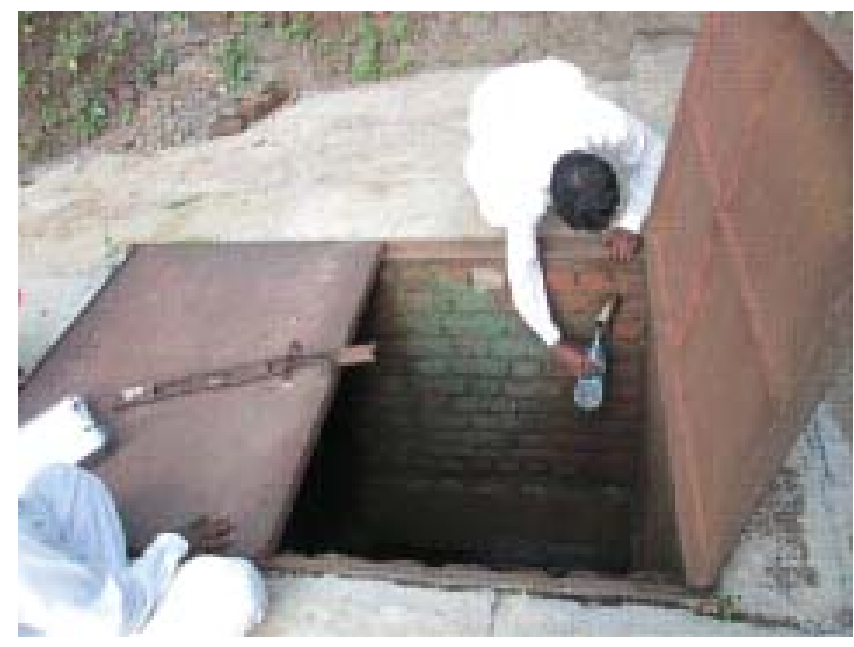

(b)

Figure 6: Springs in a relatively natural state (a) oozing out at the contact of lateritic talus deposits and basalt unit at Kirunde Spring, and a springbox built on a spring outlet to capture water (b) near Akhegani Spring.

other infrastructure. The only impact seems to be some trampling by domestic animals that use it as a water source (Figure 6).

\section{Taighat Spring}

The Taighat Spring sits above Taighat village bordering the hill station of Panchgani. The geological survey found that the spring emerges from a fracture in the lower section of the laterite rock and talus complex at 1195 meters in elevation. There are several similar fractures in the area. All are vertically oriented and trend north-south as can be seen in Figure 7. Many of these fractures are associated with springs. The springs would therefore be defined as fracture springs, but occur near the contact with the compact basalt. Spring discharge was very low and seasonal, going dry in April or May. Therefore, no discharge was measured in the hot season. The spring catchments were sparsely vegetated with some stands of Gulmohor and Nilgiri trees with a much smaller number of indigenous species like Mango (Mangifera indica), Bakul (Mimusops elengi) and Sonchapha (Magnolia champaca). Vegetation at the springs outlets consisted of open, sparse grasses and shrubs with occasional trees such as Bombax ceiba (Kate Sawar). The faunal activity observed was mainly of common city based bird species like Common Myna, Red vented Bulbul and
Land cover class was observed as :

$\begin{array}{lll}\text { Land Cover Class } & \text { Area (hectares) } & \text { Area (\%) } \\ \text { Dense Canopy } & 2.5 & 39 \\ \text { Settlement } & 0.6 & 9 \\ \text { Grassy Patches } & 3.3 & 52 \\ \text { Total } & \mathbf{6 . 4} & \mathbf{1 0 0}\end{array}$

Human pressure was high with intensive land use including roads, construction, residential and commercial (tourism) structures, wells and a number of latrines just upslope from the spring outlets. According to community members, the latrines, placed roughly 30 meters upslope of the spring outlet, have contaminated the water. This spring, as well as all of the others in the area, are no longer used for drinking and are now solely for domestic livestock, small-scale irrigation of tree plantations and car washing. There are a series of spring boxes built to harvest water, including a separate small tank below the outlet for domestic animal use (Figure 8).

\section{Umbri Spring}

Located in Umbri Village, the geological survey for this spring suggests that groundwater is recharged via a rocky laterite plateau and the slopes above the spring (Figure 9). The spring outlet occurs near the contour of 


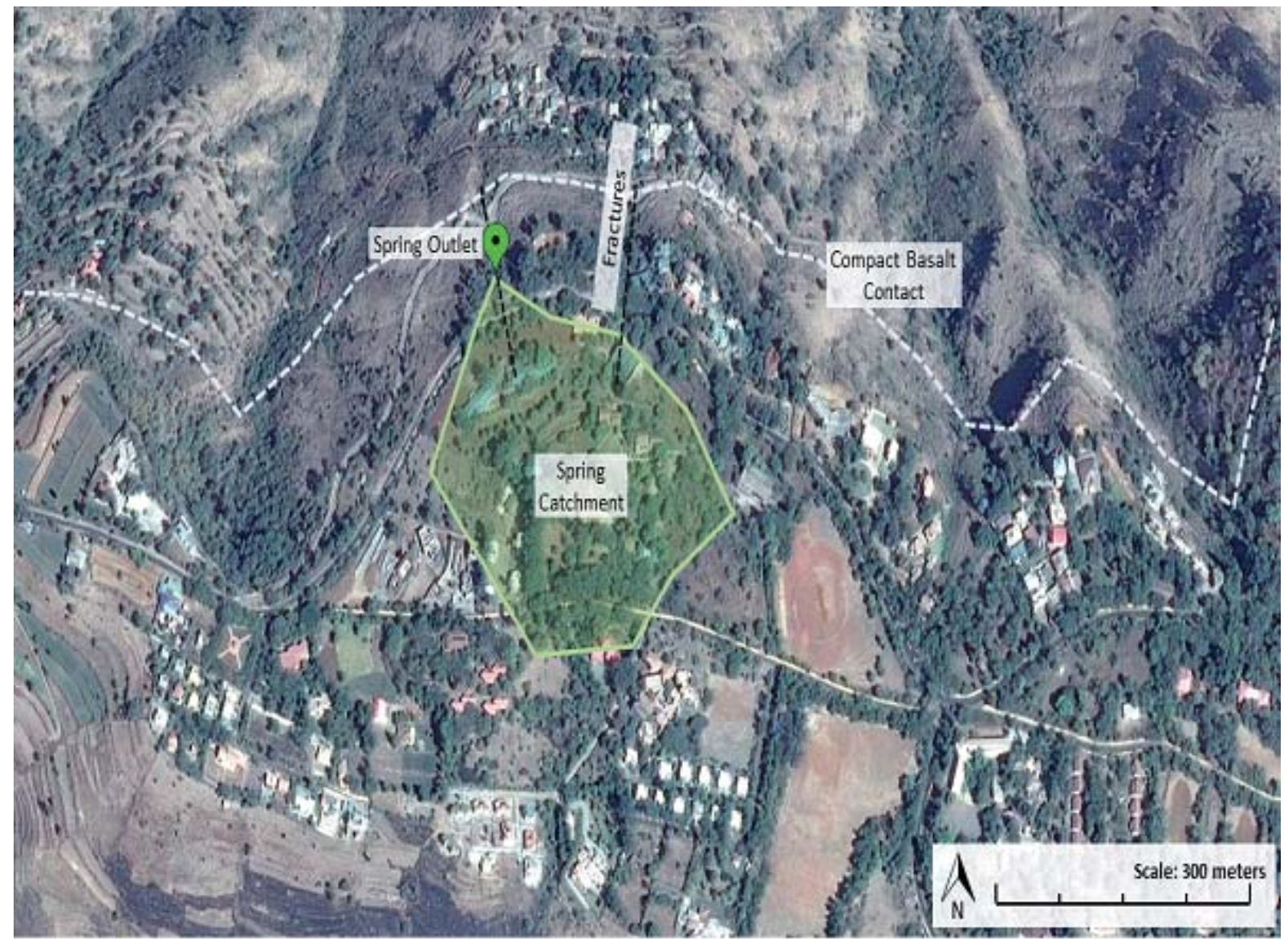

Image Source: Google Earth Image Date: December 2015

Figure 7 : Taighat Spring catchment, outlet and geological features.

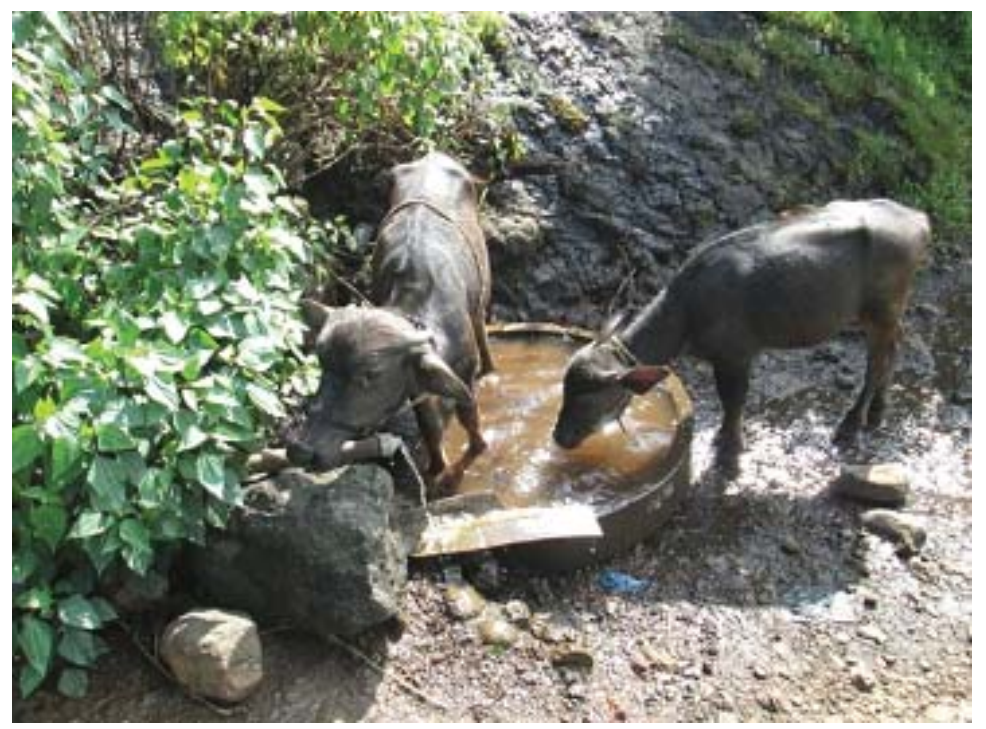

Figure 8: A tank situated at distance from a spring outlet, called a 'guzzler', used for watering domestic animals or wildlife while protecting the habitat at the natural spring outlet. 
the contact between the laterite and the compact basalt, indicating a contact spring. Discharge was measured as 5.5 liters per minute in April 2014.

The catchment is a mixture of grasslands, rocky outcrops and small patches of moderately dense shrubs. In grassland patches the catchment shows dominance of Themeda spp. with few herbs like Sonaki (Senecio bombayensis), Leucas aspera and Pogostemon decccanensis. The dense patches included presence of Pisa (Actinodaphne hookeri), Jambhul (Syzygium cuminii), Hirda (Terminalia chebula). The area surrounding the spring outlet is open with occasional tall trees and shrubs including Walunj (Salix tetrasperma), Karwanda (Carissa congesta), Toran (Ziziphus rugosa) and Phapat (Pavetta crassicaulis). The bird species mainly included Red vented Bulbul and Common Iora. Little other fauna was observed.

Land cover classes were observed as :

$\begin{array}{lll}\text { Land Cover Class } & \text { Area (hectares) } & \text { Area (\%) } \\ \text { Regenerating Forest } & 1.0 & 7 \\ \text { Rocky Area } & 0.2 & 1 \\ \text { Grassy Patches } & 9.8 & 69 \\ \text { Shrubbery } & 2.3 & 16 \\ \text { Plateau } & 1.0 & 7 \\ \text { Total } & \mathbf{1 4 . 3} & \mathbf{1 0 0}\end{array}$

Human pressure included intensive grazing, annual fires and fuel wood collection in the catchment, as well as intensive domestic animal presence at the spring outlet. The spring outlet sits above the village and is used to gravity-feed drinking water to the community centre. A springbox is built on the spring outlet, and connected nearby is an open tank for domestic animals to drink.

\section{Discussion}

\section{Hydrogeology}

Spring discharge across the springs studied averaged 10.3 liters per minute in the hot season. The aquifers were mainly composed of laterite with some vesicular basalt. All were considered contact-type springs that emerged at the lithomarge at the base of the laterite or at the contact with the compact basalt, except for the fracture-type spring at Taighat. Elevations were generally around the 1200-meter mark which marks the lower margin of the laterite plateaus in the area. Although only a small number of springs were selected for this study, these characteristics are consistent with the only detailed spring survey conducted in the area, by Naik et. al. (2002).

The only difference we observed was the presence and impact of fracture zones. Naik et. al. (2002) found

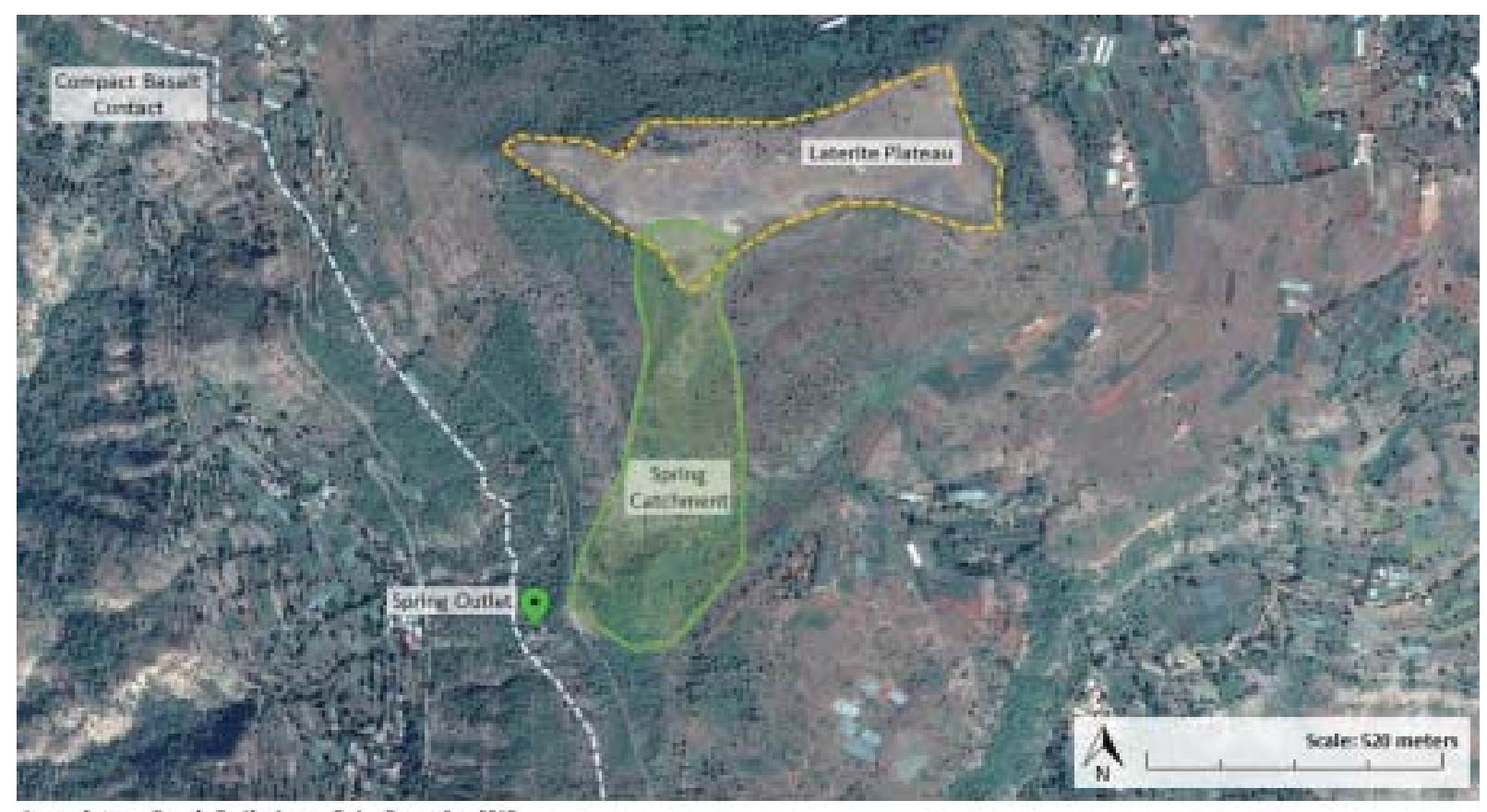

mage Seunce Goode Eath inage 0ate: Oecenter 2015

Figure 9: Umbri Spring showing spring catchment, outlet and geological features. 
Akhegani $\quad 17.867970^{\circ} \mathrm{N}$ Spring $\quad 73.786247^{\circ} \mathrm{E}$

$1170 \mathrm{~m}$

$\begin{array}{ll}\text { Godavalli } & 17.925608^{\circ} \mathrm{N} \\ \text { Spring } & 73.814197^{\circ} \mathrm{E}\end{array}$

Spring $1219 \mathrm{~m}$

Kirunde $\quad 18.011744^{\circ} \mathrm{N}$

Spring $\quad 73.690806^{\circ} \mathrm{E}$ $1222 \mathrm{~m}$

\section{Taighat}

Spring

$17.924328^{\circ} \mathrm{N}$ $73.782914^{\circ} \mathrm{E}$ $1196 \mathrm{~m}$

Umbari $17.892683^{\circ} \mathrm{N}$ Spring
15 acre catchment of basalt plateau with lateritic soil and talus slopes, with contact spring along contact with lithomarge. Hot season discharge of 15 litres per minute in 2014.

38 acre catchment of laterite plateau and talus slope with contact spring just above compact basalt contact. No hot season discharge in last few years.

39 acre catchment of laterite plateau with deep soils and dense forest, contact spring fed by fractures emerging above contact with compact basalt. Ho season discharge was 31 liters per minute in 2014.

16 acre catchment in laterite, fed by fractures and emerging at an exposed fracture - a fracture spring with seasonal discharge, goes dry by March or April every year.

36 acre catchment in talus slopes with small portion of laterite plateau. Spring emerges at contact with compact basalt.

Hot season discharge of 5.5 liters per minute
Light pressure from grazing and tree cutting. Some boundary encroachment of construction, pumping and fire. Limited pressure at outlet, but large springbox present.

Very high human pressure, urbanized spring with intensive construction, grazing, fire, agriculture and pumping from dozens of wells.

Very light human pressure due to only one habitation in the catchment. Limited tree cutting and grazing. Light domestic animal use at outlet.

High human pressure, urbanized spring. Intense grazing, construction and annual burning; latrines in the catchment led to disuse as drinking water source.

Moderate pressure due to annual burning, intense grazing, fuelwood collection, and trampling by domestic animals at outlet.
Dominated by closed-canopy, regenerating forest with diverse, native plant and animal species. Some amphibians observed at the outlet, but spring entirely covered by a large springbox used to harvest village drinking water

An urbanized catchment dominated by disturbed land cover classes such as Settlements and Fields. Overall biodiversity and vegetation cover was very low.

Catchment dominated by mature, native, multi-story forest. Varied wildlife including large mammals, leopards. Spring outlet in natural condition, with no springbox.

Catchment dominated by cleared land classes such as Settlement and Grassy Patches. Spring outlet is lightly protected with separate area for domestic animals to drink. A high proportion of non-native trees and invasive species present.

Mixed grass and shrub cover in the catchment, moderate biodiversity with grazing, fuel wood and burning pressures. 
only $12 \%$ of springs could be classified as fracture springs, and attributed little effect to fractures on the springs. This study, however, found that the majority of springs investigated were associated with fractures, even if they could not be specifically defined as fracture-type springs. Fracture zones have been proven to serve as conduits for groundwater infiltration and transmission in the Northern Western Ghats (Krishnamurthy et. al. 2004; Lie and Gudmundsson 2002; Peshwa et. al. 1987). They are therefore very likely to play a significant role in spring formation.

Fractures were also found to connect different parts of the landscape with outlets and catchment areas often geographically distant. The fractures tend to be vertically oriented and can extend from the surface down through mountains passing through all rock types, essentially connecting porous rock formations and allowing water to percolate through impervious formations. Therefore, a spring in a valley bottom may be recharged from a catchment on a mountaintop hundreds of meters above (Deolankar et. al. 1980; Kale and Kulkarni 1992; Kulkarni et. al. 1995; Peshwa and Deolankar 1990).
Fracture zones were evident at Taighat, Kirunde and Godavalli. Although not part of this study, adjacent spring sites at Kirunde were also fracture-type. These fractures tended to span rock formations including the laterite plateaus at the top of the watersheds. In the case of Kirunde and Taighat, they possibly spanned the ridgeline which would extend the catchment across the watershed boundary.

Figure 10 illustrates the typical groundwater flow paths including contact springs emerging at the base of the laterite along the contact with the compact basalt, as well as along fractures crossing numerous rock formations.

Ecology

Vegetation and animal surveys showed a large variation between springs. The Kirunde spring catchment was dominated by dense-canopy, mature forest and exhibited diversity of native plants and animals. The spring outlet was in a natural state and provided habitat to numerous species including an area leopard. In contrast, Godavalli catchment was dominated by human oriented land use such as

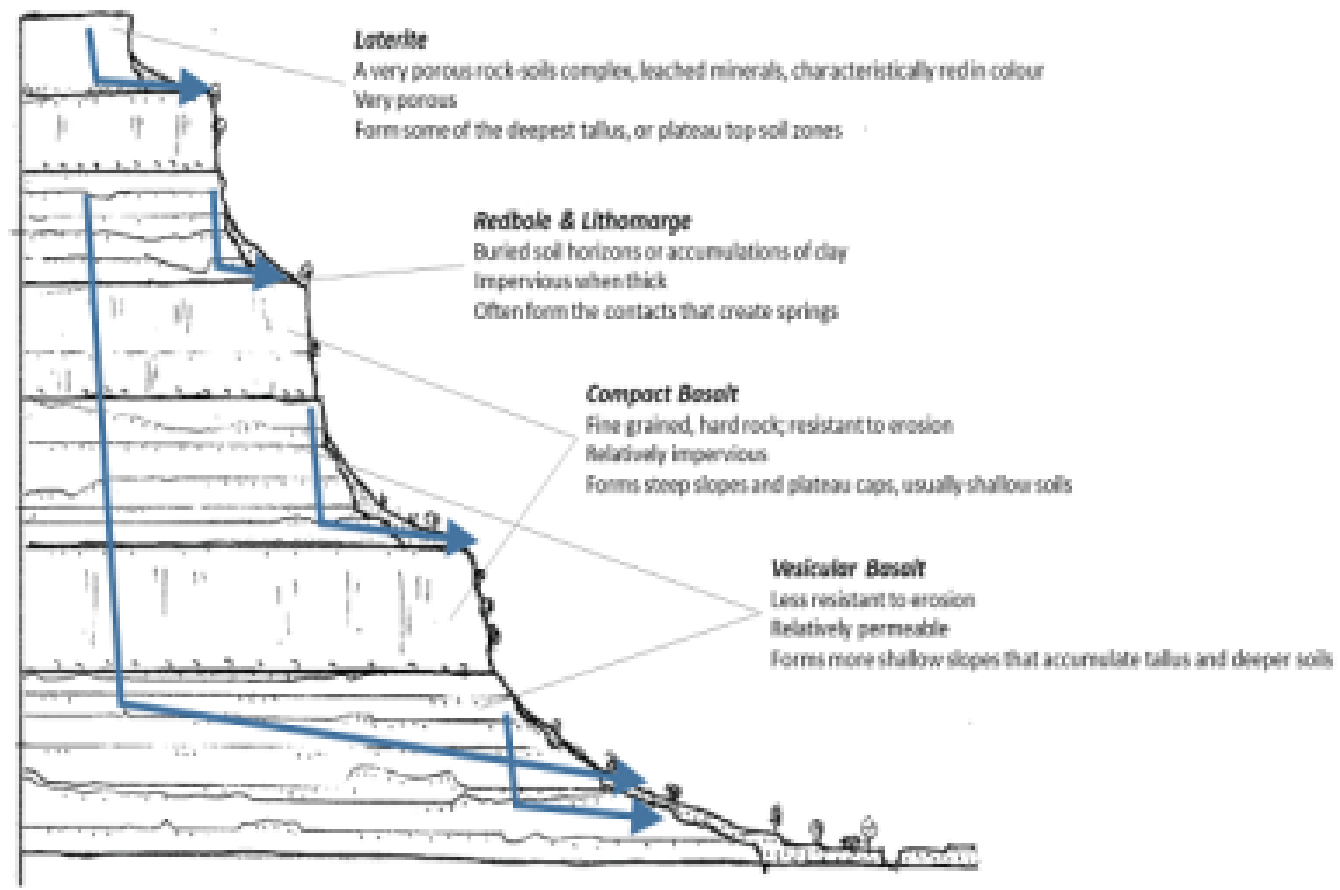

Figure 10 : Typical framework of hydrogeological units with generalized groundwater flow paths. Contact springs form when groundwater encounters an impervious material to emerge on the surface; fracture springs emerge directly from fractures. While contact springs tend to be local, associated with a porous unit overlying an impervious one, fracture springs may traverse multiple units across the landscape. Many springs observed here appeared to be hybrid systems with contact springs fed by fracture zones. 
buildings and agricultural fields, and the outlet was the site of a temple and no longer exhibits seasonal discharge. The plants and animals that were observed were mainly domestic or non-native.

Human pressures included grazing, tree cutting and fuel collection, agriculture, groundwater pumping, construction, tourism and annual burning. The impacts were reduced vegetation cover, soil loss, decreased water tables and loss of habitat and biodiversity. Spring outlets experienced similar pressures and impacts but were subject to specific issues such as intensive grazing and trampling by domestic animals leading to vegetation loss and soil compaction. The construction of infrastructure for harvesting water, such as springboxes and tanks, also led to loss of habitat.

\section{Components of a Spring Ecosystem}

It became apparent that, in this context, the definition of a spring required refinement. It was observed that springs have three distinct ecohydrologic components based on where groundwater is either recharged (the catchment), stored/transmitted (the aquifer), or ultimately discharged (the spring outlet area). See Figure 11. These components were often geographically distant and ecologically distinct with significant variation in their ecological potential in terms of native plants and animal communities, human pressures and land use.

The catchment area of a spring is where groundwater recharge occurs. This has been defined as the springshed and is conceptually similar to a watershed (Negi and Joshi 1999). It often requires a geologic survey to identify as it can be geographically separate from where the spring discharges, even occurring in a separate watershed. Catchments are spatially extensive. In this study, they averaged 11.7 hectares in size and tended to occupy plateau tops and adjacent slopes. These were often the same areas populated or used by local communities so land use could be very intensive. Degradation of the forests and soils in this area has been shown to reduce infiltration and recharge (Mehta et. al. 2008; Bonell et. al. 2010), therefore any changes in the catchment are likely to reduce spring discharge.

Spring outlets are the most visible component. This is where groundwater emerges on to the surface, generally as a point source, but sometimes as a more linear feature along a contact or fracture many meters in length, or as seep or wetland. Outlets are the points of use for humans, domestic animals and the many endemic plants and animals. High use in such a small area can lead to intensive pressure and severe impacts. Most springs near human settlements have spring boxes or tanks to harvest water. Herds of domestic animals are driven to outlets for drinking water so deforestation and erosion can be significant. Few natural pools native to spring formation remain intact therefore biodiversity may be reduced.

The aquifer is the pores in the rock that store and transmit groundwater, the component that connects the catchment to the outlet. It is harder to characterize without detailed hydrogeologic investigation. The concept of assessing or managing 'aquifer health' is not well defined (Korbel and Hose 2011). In this study, it was seen that exploitation of groundwater through pumping of wells has resulted in decreased water tables at the Godavalli where the once perennial spring

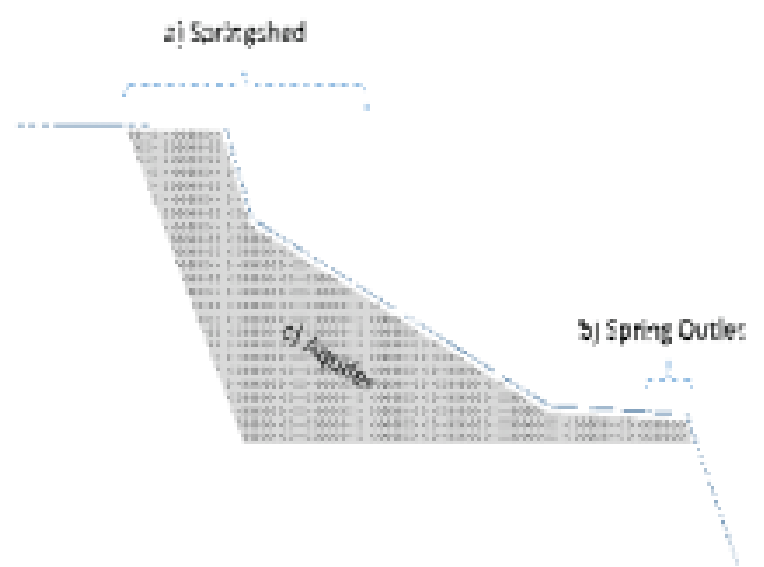

Figure 11 : Conceptual model of the components of a spring ecosystem, or springshed including the catchment or springshed (a), the outlet (b) and aquifer (c). 
is now seasonal. Improper sanitation (latrines above the spring) has led to disuse of drinking water at Taighat.

Considering these three components, it is suggested that a springshed be defined as the catchment area, the aquifer and the outlet area. This will help with recognition and acknowledgement that the source of water (outlet) is supported by an often distant recharge area (catchment) and the two are hydrologically connected by an aquifer where degradation in any component may have downstream impacts.

\section{Springshed Management Recommendations}

Spring catchment areas need to be identified and protected. While the impact of human pressures on spring discharge was not possible to define in this study, and overall discharge is likely governed by catchment size and aquifer characteristics, it is apparent at Godavalli that rapid urbanization and intensive land use have degraded ecological conditions and depleted groundwater. Construction covering almost 30\% of the catchment has likely reduced infiltration. Groundwater pumping has also greatly increased in the catchment above the spring the villages now have 12 bore wells and as many open wells. This is likely why the spring has become seasonal after many generations of perennial flow. If spring water is to be managed as a drinking water source, these types of pressures will need to be managed for the common groundwater resource.

The approach used in this study, of employing hydrogeologic field methods to identify spring recharge areas, represents a potential for targeted interventions for water security. The average catchment in this study was 11.7 hectares in size. While this is only a rough estimate, and a more rigorous delineation of the catchment may be possible using tracers or other methods, it provides a baseline for costing of spring management programmes. Restoring and protecting 11.7 hectares may be all that is needed to maintain a village drinking water source.

As much as possible the spring outlet should be protected and left in a natural state to promote biodiversity. Human pressures at spring outlets appear to reduce habitat, so spring boxes used to harvest water for communities should include a provision for a separate tank for use by domestic and wild animals.

The interconnected nature of the landscape, in terms of water resources, needs to be recognized given that spring outlets and catchments are often distant. Springs in a valley bottom may be recharged by ridge top catchments. This holds for groundwater feeding nallas in the valley bottoms - rivers and streams may be dependent on protecting plateaus. Due to plateaus being flat, spatially extensive and layered with deep weathering, and often deep soils and rich vegetation, virtually all-percolating water moves through these formations before emerging as springs or entering fracture systems feeding regional groundwater (Deolankar et al. 1980; Duraiswami et. al. 2012; Larsen and Gudmundsson 2010). This gives additional impetus to protect plateaus in the North Western Ghats, and also makes landscape lineaments and fracture zones potential candidates for protection to improve groundwater recharge.

Methods to assess and monitor the ecological condition of springs need to be developed for improved management. Based on this study, a relative assessment could be made based on several factors including the extent and intensity of observed human impacts, the proportion of land cover classes in a natural state - for example, how much of the spring was under Dense Canopy versus Settlement, and the amount of habitat that appeared intact during field observation including the degree to which the spring outlet had been altered with tanks, pipes and other infrastructure. If it is assumed that these study locations represent the full spectrum of ecological conditions, with 'High' condition represented by Kirunde and its historic, native conditions, and the other end of the spectrum being Godavalli, an urbanized spring heavily impacted by all manner of observed human activity and thus considered 'Low' condition, then all other study sites could be similarly ranked.

\section{Conclusions}

Spring discharge appears largely governed by geology and aquifer characteristics, but may be reduced under intensive land use such as the pressures of urbanization and over pumping of ground water. Further any reduction in discharge may negatively impact biodiversity if spring outlets become seasonal. Grazing, fire, construction, pumping and fuelwood collection were common human pressures effecting nearly all springs.

Spring systems have three distinct components, a catchment, an outlet and an aquifer. These components hydrologically connect separate parts of the landscape from mountaintops to valley bottoms. This has potential ecological implications for land use and water management - for example, construction and mining on plateau tops may reduce spring discharge and base flows in rivers. 
Springs are essential components of the freshwater resources in the North Western Ghats. Yet, despite the importance of springs to people and the environment, there is little awareness, public investment, and research.

\section{References}

Aravind, N.A., N.A. Madhyastha, G.M. Rajendra, A. Dey (2011): The Status and Distribution of Freshwater Molluscs of the Western Ghats. In: The Status and Distribution of Freshwater Biodiversity in the Western Ghats, India, Molur, S., K.G. Smith, B.A. Daniel and W.R.T. Darwall (Compilers). Cambridge, UK and Gland, Switzerland : IUCN, and Coimbatore, India : Zoo Outreach Organisation, pp. $59-72$.

Bassi, N., M.D. Kumar, A. Sharma, P. Pardha-Saradhi (2014): Status of Wetlands in India: A Review of Extent, Ecosystem Benefits, Threats and Management Strategies, Journal of Hydrology: Regional Studies, 2, pp. 1-19.

Bonell, M., B.K. Purandara, B. Venkatesh, J. Krishnaswamy, H.A.K. Acharya, U.V. Singh, R. Jayakumar, N. Chappell, N. (2010) : The Impact of Forest Use and Reforestation on Soil Hydraulic Conductivity in the Western Ghats of India : Implications for the Surface and Sub-Surface Hydrology, Journal of Hydrology, Vol. 391, pp 47-62.

Bryan, K. (1919) : Classification of Springs. The Journal of Geology, Vol. 27, No. 7 (Oct. - Nov., 1919), pp. 522561.

Deolankar, S.B. (1980): The Deccan Basalts of Maharashtra, India - Their potential as Aquifers. Groundwater, Vol. 18, No. 5, pp. 434-437.

Deolankar, S.B., J.G. Mulay, V.V. Peshwa (1980) : Correlation between photolineaments and the movement of groundwater in the Lonavala area, Pune District, Maharashtra, India. Journal of Indian Society of Remote Sensing. Photonirvachak, v. 8, pp. 49-52.

Deolankar, S.B., H. Kulkarni (1987): Evaluation of transmissivity of Deccan basalts of Maharastra, India, using aquifer response from large-diameter dugwells. Mem XVIII IAH - Hydrogeology of Rocks of Low Permeability, Tucson, Arizona, pp. 622-630.

Deshmukh, S.S. (1988): Petrographic Variations in Compound Flows in Deccan Traps and Their Significance. In: K.V. Subbarao (ed.), Deccan Flood Basalts. Mem. Geol. Soc. India, no.10, pp. 305-319.

Duraiswami, R. A., Das, S. and Shaikh, T. N. (2012) : Hydrogeological Framework of Aquifers in the Deccan Traps, India: Some Insights, Memoir 80,
Geological Society of India, pp. 1-15

Duraiswami, R. A. (2013) : Pahoehoe-aa Transitions in the Lava Flow Fields of the Western Deccan Traps, India - Implications for Emplacement Dynamics, Flood Basalt Architecture and Volcanic Stratigraphy, Journal of Asian Earth Sciences, Vol. 84, pp. 146-166.

Kale, V.S., H. Kulkarni (1992) : IRS-1A and Landsat Data in Mapping Deccan Trap Flows around Pune, India: Implications for Hydrogeological Modeling. Archives, International Society of Photogrammetric and Remote Sensing, v. 29 (B7), pp. 429-435.

Korbel, K. L., G.C. Hose (2011) : A Tiered Framework for Assessing Groundwater Ecosystem Health. Hydrobiologia, Volume 661, Number 1, pp. 329-349.

Krishnamurthy, V., R.A. Duraiswami, V.B. Joshi (2004) : Application of Remote Sensing Tools in the Delineation of Saline Groundwater Zones in Hard Rock Areas: A Case Study From Pune District. Global Spatial Data Infrastructure 7th Conference, February 2-6, Bangalore.

Kulkarni, H.C., S.B. Deolankar (1995) : Hydrogeological Mapping in the Deccan Basalts: An Appraisal. Journal, Geological Society of India, v. 46, pp. 345352.

Kulkarni, H., S.B. Deolankar, A. Lalwani, B. Joseph, S. Pawar (1995): Hydrogeological Framework of Deccan Basalt Groundwater Systems, India. Hydrogeology Journal (Springer-Verlag), v. 8(4), pp. 368-378.

Kulkarni, H.C., S.B. Deolankar (1997) : Dugwell Inflows from Shallow Deccan Basalt Aquifers. Journal, Geological Society of India, v. 49, pp. 705-714.

Larsen, B., A. Gudmundsson (2010): Linking of Fractures in Layered Rocks: Implications for Permeability, Tectonophysics, Vol. 492, Issue 1, pp. 108-120.

Lie, H., A. Gudmundsson (2002) : The Importance of Hydraulic Gradient, Lineament Trend, Proximity to Lineaments and Surface Drainage Pattern for Yield of Groundwater Wells on Askøy, West Norway, NGU Bulletin, 439, pp. 51-60.

Mehta, V. K., P.J. Sullivan, M.T. Walter, J. Krishnaswamy, S.D. DeGloria (2008) : Impacts of Disturbance on Soil Properties in a Dry Tropical Forest in Southern India, Ecohydrology, 1, pp. 161175.

Naik, P. K., Awasthi, A. K., Mohan, P. C. (2002): Springs in a Headwater Basin in the Deccan Trap Country of the Western Ghats, India, Hydrogeology Journal, Vol. 10, pp. 553-565.

Negi, G. C. S., V. Joshi (1999) : Geohydrology of Springs 
in a Mountain Watershed: The Need for Problem Solving Research, Current Science, Vol. 71, No. 10, pp. 772- 776.

Peshwa, V. V., J.G. Mulay, V.S. Kale (1987) : Fracture Zones in the Deccan Traps of Western and Central India: A study Based on Remote Sensing Techniques, Journal of the Indian Society of Remote Sensing, Vol. 15, No. 1, Photonirvachak, pp. 9-17.

Peshwa, V.V., S.B. Deolankar (1990) : Remote Sensing of Shallow Unconfined Deccan Basalt Aquifers from Maharashtra State, India. Proceedings, International Symposium on Remote Sensing and Water Resources, IAH/NSRSD, Enschede, The Netherlands, pp. 515-523.

Space Applications Centre (SAC) (2011): National Wetland Atlas. SAC, Indian Space Research Organisation, Ahmedabad.

Walker, B., J.A. Meyers (2004): Thresholds in Ecological and Social-Ecological Systems: A Developing Database. Ecology and Society 9(2): 3 . Retrieved on 08.05.2015 (URL: http:// www.ecologyandsociety.org/vol9/iss2/art3/)

Watve, A. (2013) : Status review of Rocky plateaus in the northern Western Ghats and Konkan region of Maharashtra, India with recommendations for conservation and management. Journal of Threatened Taxa. 2013; 5(5) : 3935-3962.

Watve, A., A.S. Thakur (2006) : Ecological Studies of Lateritic Plateau Habitats in Northern Western Ghats, pp. 22-28 in H. N. Pandey and S. K. Barik (eds.), Ecology and Conservation of Plants and Ecosystems in India. Regency Publications, New
Delhi.

Widdowson, M. (1997) : Tertiary Palaeosurfaces of the SW Deccan, Western India : Implication for Passive Margin Uplift. In: Palaeosurfaces: Recognition, Reconstruction and Palaeoenvironmental Interpretation (ed.) Widdowson M, Geol. Soc. Spec. Publ. 120 221-248.

Widdowson, M., K.G. Cox (1996) : Uplift and Erosional History of the Deccan Traps, India : Evidence from Laterites and Drainage Patterns of the Western Ghats and Konkan Coast; Earth Planet. Sci. Lett. 137, pp. 57-69.

Widdowson, M., Y. Gunnell (1999): Lateritization, geomorphology and geodynamics of a passive continental margin: The Konkan and Kanara coastal lowlands of western peninsular India; Spec. Publ. Int. Assoc. Sediment. 27, pp 245-274.

Widdowson, M. (1997) : Tertiary Palaeosurfaces of the SW Deccan, Western India : Implication for Passive Margin Uplift. In: Palaeosurfaces: Recognition, Reconstruction and Palaeoenvironmental Interpretation (ed.) Widdowson M, Geol. Soc. Spec. Publ. 120 221-248. Widdowson, M., K.G. Cox (1996) : Uplift and Erosional History of the Deccan Traps, India: Evidence from Laterites and Drainage Patterns of the Western Ghats and Konkan Coast; Earth Planet. Sci. Lett. 137, pp. 57-69.Widdowson, M., Y. Gunnell (1999): Lateritization, geomorphology and geodynamics of a passive continental margin: The Konkan and Kanara coastal lowlands of western peninsular India; Spec. Publ. Int. Assoc. Sediment. 27, pp 245-274. 